\title{
MAGNIFICENT CENTURIES AND ECONOMIES OF DESIRE
}

\author{
In 2000 when we [post-Soviet migrants] came, here in Turkey they \\ did not have cell phones or even washing machines. . . . They only \\ just came down from the hills.
}

—A Moldovan man speaking about his first impressions of Turkey, interview June 21, 2011

When they first came here in the early 1990s, they were willing to do anything; they were hungry and came without fathers or brothers.

-A Turkish shopkeeper speaking about post-Soviet women migrants, interview May 8, 2007

My grandfather used to come here to trade back in his youth; I don't know what he traded exactly, but my grandmother told me he used to come here, back before the war.

-A Gagauz woman speaking of pre-Second World War trade links to Turkey, interview June 25, 2005

Turkey is quite pleased with the number of Russian tourists who visit, which exceeds three million a year, having Russian daughters-in-law, and trading with the Russians.

—Hasan Kanbolat, columnist for Today's Zaman, 2012

The arrival of post-Soviet women in Turkey beginning in the early 1990s struck the Turkish public as a dramatic event, but the encounter of Turks and people from the former Soviet Union had significant historical precedent. Some historical ties were passed on via oral tradition, like the pre-Second World War trade ties mentioned in the epigraph above, but more recently popular media has fostered other senses of historical connection, particularly in regard to a glorious Ottoman past. In what is probably the most widely encountered example of "Ottomania," a laudatory portrayal of the Ottoman Empire that has swept Turkey, the telenovela The Magnificent Century (Muhteşem Yüzyll) opens with the commanding, young Süleyman the Magnificent out on a hunting expedition. He 
receives news that his father has died, making him the next sultan of the Ottoman Empire. The series goes on to trace Süleyman's reign, which extended over forty-five years (1520-1565) and ultimately expanded the Ottoman Empire to encompass lands stretching from the Persian Gulf to the Danube River, bringing thirty to fifty million people under the direct control of the empire (Fromkin 1989, 34; Kaya and Tecmen 2011, 15-20).

Early in the series Süleyman is swept off his feet by the lively, fair Alexandra, a slave recently brought as a young adult from the outer regions of the Russian Empire. The series features palace intrigues and intimate lives, with a focus on Süleyman and Alexandra, who becomes Süleyman's wife, known as Hürrem and a powerful figure in her own right. This telenovela is just the latest of a now established Turkish media tradition, but this part historical drama, part soap opera is the first of its genre to focus on the intimate practices of a popular Ottoman ruler, and the first to feature his sometimes reviled, sometimes revered consort, Hürrem (Batuman 2014). ${ }^{1}$ The Magnificent Century has also brought intimate ties between Turkey and Russia to the fore of public discourse.

As of January 2014 The Magnificent Century completed its fourth and final season, garnering record-breaking viewership, especially in Turkey but also throughout the Middle East, the former Soviet Union, and Eastern Europe. ${ }^{2}$ In addition to causing a stir with its portrayal of a venerated sultan among libidinous women, the telenovela also embodies the intangible power of the imagination at play in the encounter of Turks and post-Soviet women in Turkey today. Although the series may not be the primary factor compelling women to migrate, it creates a sense of possibilities for them. For a Turkish viewership, the telenovela affirms a stereotype about "Russian" women as embodying dangerous sexuality, a quality that, according to the storyline of The Magnificent Century, had an integral role to play in the weakening of the Ottoman Empire.

The television series highlights a number of issues at stake since the early 2000s as Turkey has come to embrace Ottomania as portraying the height of political and cultural influence in the region (Potuoğlu-Cook 2006, 2008; Toksabay and Villelabeitia 2011; Batuman 2014). Despite the unprecedented popularity of The Magnificent Century, some found the telenovela's depiction of Süleyman to be in poor taste. As one commentator wrote on the intense debates about The Magnificent Century, "The Islamic World's version of America's culture wars is playing out in a lavishly recreated 16th century palace" (Rohde 2012a). Prime Minister Recep Tayyip Erdoğan and his Justice and Development Party (AKP) have widely sought to promote Turkey's "soft power" through the glorification of the Ottoman Empire, with the concomitant image of Turkey as its successor, a political aim that did not fit well with the racy soap opera/historical drama (Finkel 2012; Aydos 2013). In a speech 
in December 2012 Erdoğan called for federal judicial action against the show's producers. Erdoğan and his supporters saw the series as sullying the name of the most preeminent Ottoman ruler, known as Süleyman the Magnificent in European literature and Kanuni Sultan Süleyman, or "Süleyman the Lawgiver," in the Muslim world. As the tenth and longest reigning ruler of the Ottoman Empire, Süleyman is widely revered. He is noted for bringing about extensive reforms to the Ottoman legal system, substantially expanding the reach of the Ottoman Empire to encompass territory from the banks of the Danube River to nearly the entire Middle East, and for being an avid supporter of the arts and culture in his empire. He was also the first sultan in the Ottoman dynastic family that spanned thirty-seven generations to break with tradition and marry a woman from his harem (Peirce 1993, 61; 2015).

Erdoğan has pointed to The Magnificent Century's rendering of Süleyman as cavorting with women and imbibing wine as outrageous. Erdoğan and his supporters insist the series is historically incorrect, casting Süleyman as an imperfect and morally corrupt ruler. In realpolitik terms, they are sensitive to anything that could potentially detract from Turkey's role as a pivotal player in the region (Akyol 2012; Kenyon 2013). In spite of considerable support for Erdoğan's position, and with more than seventy thousand complaints flooding into the television network's offices following the first airing of the series in January 2011, The Magnificent Century also earned the distinction of being avidly watched by over two hundred million viewers in as many as fifty-six countries, including Russia, Central Asian states, and elsewhere in the former Soviet Union (Rohde 2012b; Global Agency 2014). ${ }^{3}$

\section{Mobility and Cartographies of Desire}

In the twenty-first century, even prior to the debut of The Magnificent Century, the presence of Russian-speaking women in Ottoman harems occupied a visible place in the popular imagination of both Russian speakers and Turks. I first learned of Alexandra, or "Roxelana," as Russian-speaking migrants often referred to Süleyman's wife, Hürrem, in 2002, nearly nine years before The Magnificent Century first aired. As Irina, an exotic dancer from Ukraine who joined me in visiting several tourist sites during the early stages of my research, explained, Hürrem was born Alexandra Anastasia Lisowska. ${ }^{4}$ She was of Ukrainian/Ruthenian/ Polish extraction and the daughter of an Orthodox priest and was in Süleyman the Magnificent's harem before he chose to marry her in 1534 (Mansel 1995, 83; Peirce 1993, 2015). ${ }^{5}$ Irina enthusiastically described Roxelana's significance for her peers and, she argued, for the Turkish men she encountered. She insisted that we visit the Süleymaniye Mosque, where Irina led me to Hürrem/Roxelana's 
tomb located next to the main mosque. ${ }^{6}$ Irina recounted that women love to imagine themselves festooned with lavish clothing and commanding a sultan's attention, as Roxelana is widely imagined to have done. To emphasize her point Irina struck a come hither pose, elaborating that Russian women simply drive Turkish men crazy with their sex appeal.

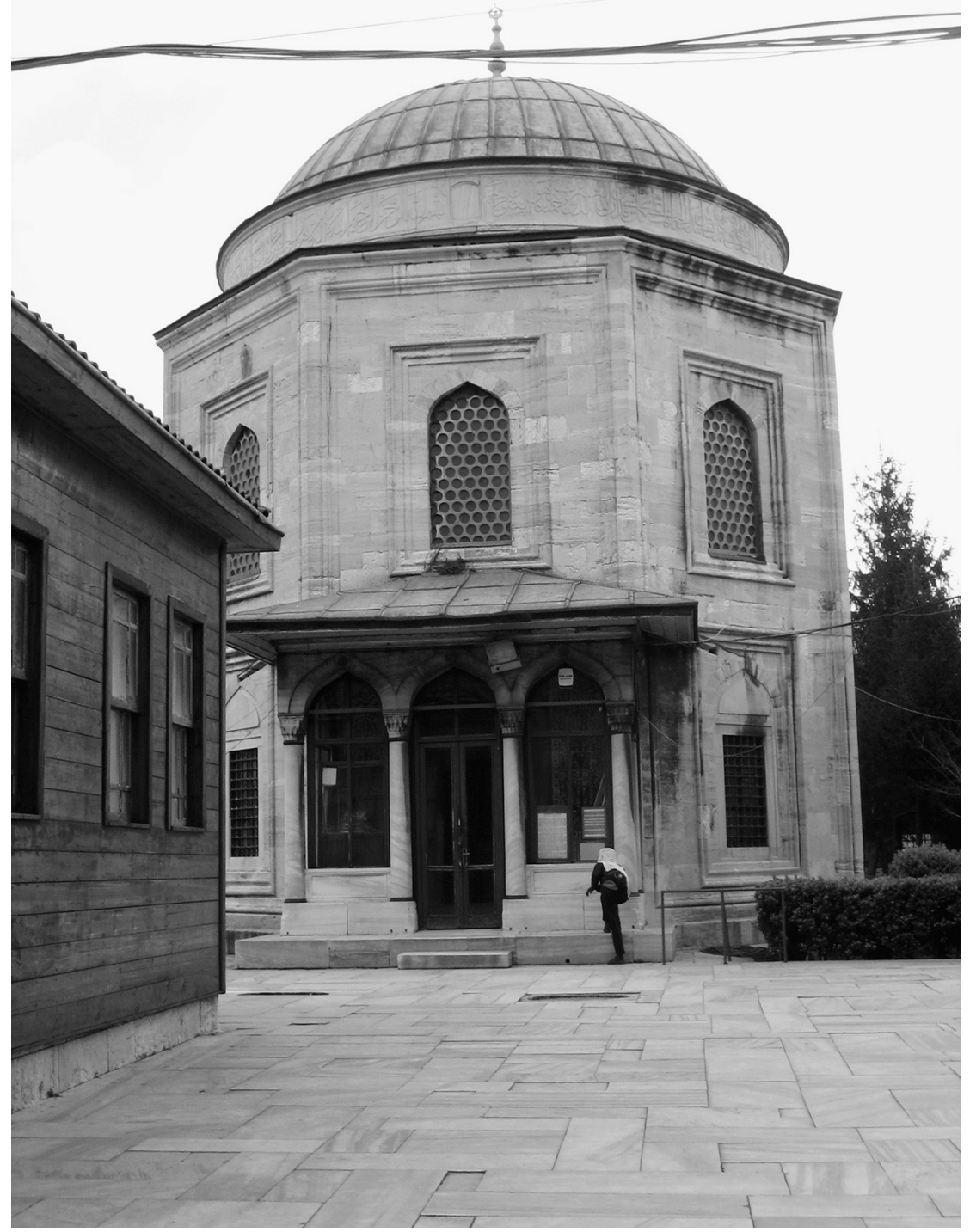

FIGURE 6. Hürrem's tomb beside the Süleymaniye Mosque. Photograph by author, 2003. 
Like Irina, in conversation other people invoked the "long tradition" of concubinage and courtesans in the region, and they emphasized the way in which women could rise from such a station to one of power and influence in the Ottoman court. ${ }^{7}$ Most often both Russian speakers and Turks I met referred to these women as being ethnically "Russians" (in Russian, russkie; in Turkish, Rusça, Rusçalar, pl.). In fact, however, women in the harem were from a range of backgrounds, even if traditionally women from Circassia, a region

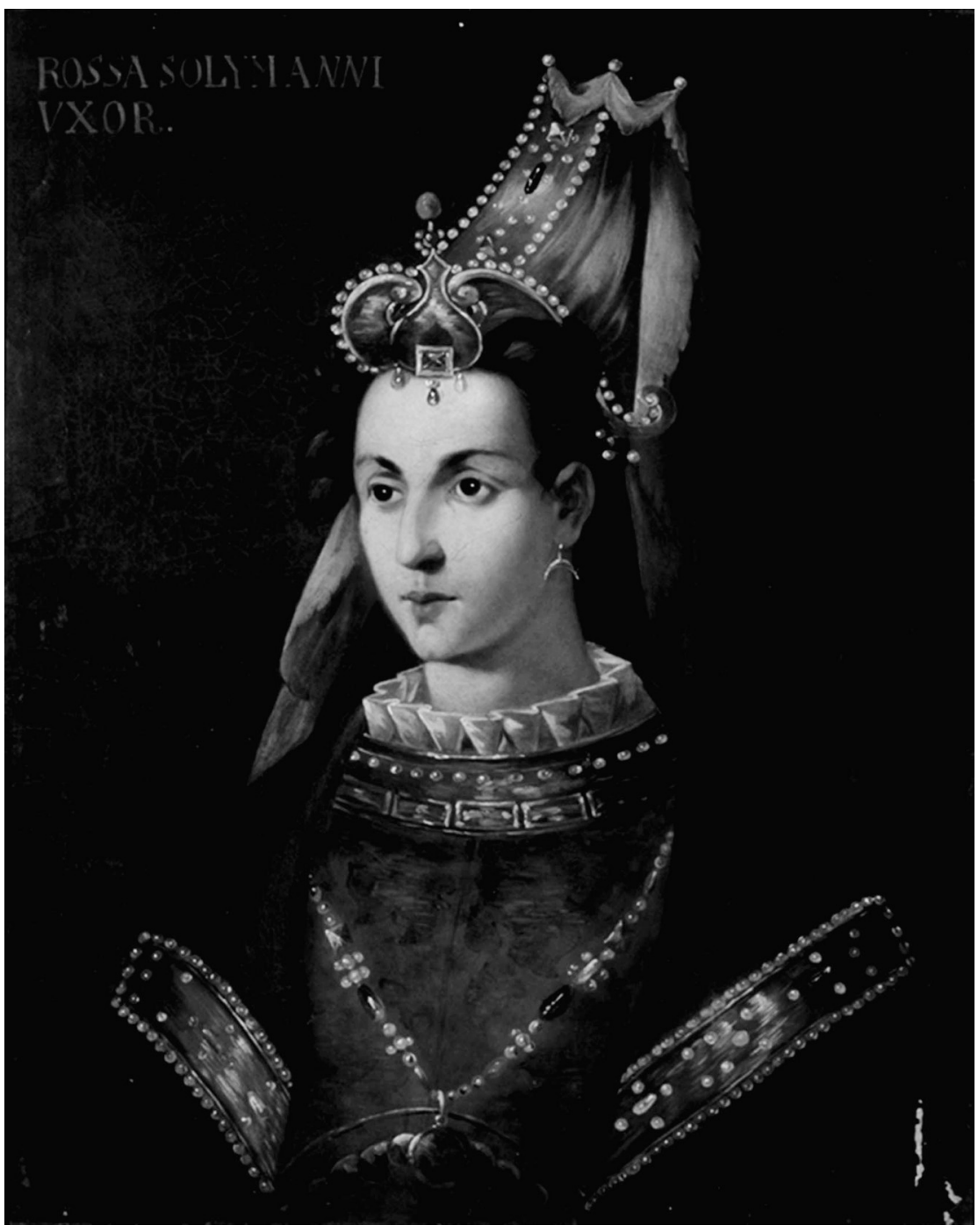

FIGURE 7. Haseki Hürrem Sultan or Roxelana. By Anonymous (www.topkapipalace.org). 
on the border of southern Russia and Georgia, were preferred slaves among the elite of the Ottoman Empire (Erdem 1996, 61). ${ }^{8}$ While the women sent to Istanbul did not all rise to positions of power like Hürrem, the presence of "Russian" women in the Ottoman harems was something that was historically well known throughout the region, even entering into oral tradition. As one historian writes, "For centuries in the Caucasus, mothers sang a lullaby over their daughters' cradles, beginning, 'Live among diamonds and splendor as the wife of a Sultan'” (Mansel 1995, 81).

Haseki Hürrem Sultan's life represents the most celebrated instance of a concubine rising to a position of power. ${ }^{9}$ Hürrem went on to wield wide powers in the Ottoman court, including by maintaining diplomatic ties with heads of state such as the king of Poland and establishing massive mosque complexes across the Ottoman Empire in Mecca, Medina, and Jerusalem. Hürrem's important political role was virtually proclaimed by the enormous mosque complex that Sultan Süleyman had built in her name in Istanbul; it was the only such complex ever built by a sultan for his wife or concubine during his lifetime (Peirce 1993, 205). ${ }^{10}$ The mosque complex remains today, with a functioning mosque and regional hospital in its place, and the neighborhood in which the complex is located is called "Haseki," in honor of Hürrem. ${ }^{11}$ Hürrem's story is one both Turks and post-Soviet women often mentioned as an example of how Russians and Turks have a long history of erotic encounters, especially in Istanbul, a "site of desire" that The Magnificent Century has compellingly portrayed.

\section{Istanbul as a Site of Desire}

The Magnificent Century encapsulates a long-term configuration of "sites of desire," what Lenore Manderson and Margaret Jolly have called a "fluid terrain in the exchange of desires" $(1997,1)$; both migrant women and contemporary Turks widely imagine the Ottoman Empire as a once opulent, alluring center of global power, something to harken back to with nostalgia, and sometimes imbued with an aura of the erotic (Potuoğlu-Cook 2006). In a contemporary period marked by the hypermobility of post-Soviet women into Turkey, an affirmation of interethnic erotic ties, specifically between Turks and women from regions of the former Soviet Union, has seen a florescence. Cartographies of desire for some in Turkey are based in a specific historical trajectory that is, in part, exemplified by The Magnificent Century but also grounded in Turkey's place within a broad Eurasian imaginary.

A dramatic increase in mobility has been central to bringing post-Soviet women into the purview of a Turkish male gaze since the early 1990s, but the broader realm of the imagination is also key. As a number of scholars compellingly argue 
in their work on the intimate lives of transnational Filipinas, intimate encounters do not simply happen but are forged within concrete historical contexts where mutual imaginaries are constituted. In the case of the Philippines following the Second World War the presence of US military bases shaped intimate connections and brought about a history of "mail order" or "correspondence" marriage between men from North America and Filipinas; more recently, the geopolitical power of Japan and South Korea has brought about flows of gendered labor from the Philippines to those countries (Constable 2003; Faier 2009; Cheng 2010). Just as Filipinas are drawn to take up intimate ties with men from North America, South Korea, or Japan as part of a long-term political economy in which these countries represent sites of opportunity, I argue here that images of historical Ottoman economic power and opulence are part of what draws post-Soviet women into intimate ties with Turkish men. These historical images also come to be imbricated in intimate ties and ways of imagining the other, wherein Turkish men can imagine post-Soviet women through a prism of Süleyman's transgressive relationship to the exotic Hürrem, and post-Soviet women can romanticize the potential of relationships with Turkish men via a narrative of Hürrem's ultimate triumph as the wife of one of the most powerful and erudite sultans of the Ottoman Empire.

As a number of scholars have shown (Manderson and Jolly 1997; Stoler 2002), these "cartographies of desire," or the ways history, politics, and the imagination inform the shape desire takes in a given location, resonate throughout colonial relationships. The Turkish-post-Soviet matrix, however, highlights just how complicated and nonbinary cartographies of desire can be. A simple "white = power" and "black/brown = oppressed" does not work in this instance. Scholars have written extensively on the way Euro-American colonial histories play into the construction of racial categories, gendered intimate practices, and the shape power takes, including in North Africa, India, Southeast Asia, and China (Fanon 1963; Nandy 1983; Stoler 2002; Constable 2003). However, few scholars have considered how the politics of race and desire unfold when economic capital is held by racially "nonwhite" men and symbolic capital in the form of education and sex appeal is held by "white" women who are, nonetheless, economically unstable and therefore mobile. ${ }^{12}$ The idea of intimate practices as interwoven with different types of power, and not just danger (Vance 1982), destabilizes simple binaries such as oppressed/oppressor, black/white, rich/poor, pleasure/ danger, or European/non-European.

In featuring the relationship between Süleyman the Magnificent and Hürrem/ Roxelana in the storyline of The Magnificent Century, the television series signals the long-term contested relationship between Russia and Turkey. The 
Ruthenian woman in the historical figure of Hürrem takes a prominent place in the story portrayed in the series and in some ways could reflect the not uncommon long-term intimate ties between Turkish men and post-Soviet migrant women in urban Turkey today. The widespread viewership in Russia, as well as across the FSU and Eastern Europe, points to the ways that imagination is being commonly forged throughout this region of Eurasia, but possibly also to a fascination with an opulent Ottoman past that is intertwined with the history of a Russian empire. The Magnificent Century is part of a long history of encounters in the region, where borders, intimacy, and mobility have come together to forge a particular backdrop to the ties between Turkey and regions of the former Soviet Union. The encounters between contemporary migrant Russian speakers and Turks are informed by a cultural politics that has emerged over hundreds of years.

\section{From Byzantium to the Jazz Age}

The migrants and Turks I came to know in Istanbul did not always know the details of the centuries of interactions between peoples from the regions of present-day Turkey and the former Soviet Union, but they were aware that ties between the two regions extend back over a thousand years. Especially for people living near the border of Turkey and Georgia or Azerbaijan, the twentiethcentury history of Russian (and then Soviet) dominance in the region loomed large, with Turkey caught between increasingly entrenched political camps (Reynolds 2011); when Turkey eventually became a member of NATO and a US ally after the Second World War, communities of coethnics and families were divided for several decades (Pelkmans 2006). ${ }^{13}$ Even after the end of the Soviet Union in the early 1990s, the Turkish public tended to have a deep-rooted suspicion of all things "Russian" as being politically suspect (Keyder 1999), and former Soviet citizens could be quick to dismiss Turkey as a place lacking "culture" (kul'tura). ${ }^{14}$ However, this simplification of the relationship between Russia and Turkey elides a varied history, even of the twentieth century, when some Turkish and Soviet allegiances emerged in the aftermath of the First World War (Kınıklığlu and Morkva 2007; Reynolds 2011) and when, in the 1920s, Turkey accepted refugees from the Soviet Union, before abruptly closing the border as the Cold War encroached. ${ }^{15}$ With the warming of relations in the 1990s and early 2000s, made visible in the myriad border crossings, Turkey and the former Soviet Union, but especially Russia, have undergone a profound repositioning of cultural exchange and realignment of political power that in some ways echoes encounters from hundreds of years earlier. 


\section{"East," "West" and the Ottomans}

Significant ties between Russian-speaking people and the region of present-day Turkey extend back at least as far as the fourth century, when Constantinople was founded as the capital of the Eastern Roman Empire and a schism between "East" and "West" first emerged. While the symbolic divide that is often invoked in bracketing the region of the former Soviet Union and Turkey apart from the "West" is not a fixed one (Tolz 2011), it could be seen in terms of age-old allegiances. ${ }^{16} \mathrm{In}$ the fifth century the Western Roman Empire became fractured and the Eastern Roman Empire, which by the late tenth century nominally included the kingdom of Kievan Rus', a federation of East Slavic tribes, solidified and thrived with Constantinople at its center until the fall of Constantinople to the Ottomans in 1453. Not infrequently migrants I came to know from Belarus, Ukraine, Moldova, or Russia referred to a celebrated Byzantine past as one to which they felt a connection; as one migrant told me, "Of course, we are drawn to more than just work here-after all, our people were here even before the Ottomans, our religious foundations are here." Eastern Orthodoxy is one of the many historical ties that especially non-Muslim Russian speakers invoke as connecting them to the region of present-day Turkey.

The origins of Kievan Rus', widely invoked as the precursor to the Russian Empire (but also claimed by Belarus and Ukraine as a geopolitical ancestor), are closely linked to Byzantium, and specifically Constantinople, as the seat of Eastern Christianity. With the consolidation of various Slavic tribes in the midninth century, the state of Kievan Rus' emerged. The Rus' sought to secure trade partnerships and expand territory, and to this end over a span of barely two hundred years (860-1043), they sailed down the Bosphorus and attacked Byzantium multiple times (Bréhier 1977, 102, 176; Herrin 2007, 116). Byzantine coins excavated at what was the ancient city of Gorodishche (the present-day Russian city of Novgorod) attest to trade relations that were established dating back to the early tenth century (Herrin 2007, 137). ${ }^{17}$

By the time of these early cultural and economic exchanges, regular incursions by the Rus' against Constantinople resulted in a number of treaties granting Rus' merchants preferential access to trade with Byzantium (Bréhier 1977, 102). By 987 terms stipulated such details as how much silk Kievan Rus' could ask for in exchange for the slaves, wax, and honey it was offering, and how many Varangian warriors would be contributed to the Byzantine forces (Browning 1992, 101; Herrin 2007, 137). ${ }^{18}$ Prince Vladimir was keen on allying his new state with the Byzantine Empire, and soon after his marriage in 987 to Anna Porphyrogenita (Anna Vizantiiskaia in Russian), he converted to Christianity and imposed the belief across his lands, calling for the destruction of "idols of paganism," 
widespread baptisms, and the construction in Kiev of two cathedrals ornately decorated with Byzantine inspired mosaics and icons (Bréhier 1977, 154; Herrin 2007, 114). ${ }^{19}$ Byzantium became the preeminent seat of power that served to fortify the foundation of the Rus' as a Christian state. Nevertheless, prior to its eventual downfall under the onslaught of the Mongols (1237-1240), Kievan Rus' continued to orchestrate a number of attacks on the Byzantine Empire, seeking to extract favorable trade treaties and strategic positioning of Rus' warriors in Byzantine structures of power, and on occasion also creating alliances with the empire in its attempts to fend off the marauding forces of Bulgars from the north, Arabs from the south and east, and, ultimately, Turks. With the rise of Muscovy as a cultural center beginning in the thirteenth century, ties to Byzantium continued, but geopolitical circumstances compelled Muscovy and then the emerging Russian Empire to forge alliances with the Ottomans; in 1453 Mehmed II, also known as Mehmed the Conqueror or Fatih Sultan Mehmed, conquered Constantinople, bringing about the eventual end of the Byzantine Empire. ${ }^{20}$

The relationship between the Russian Empire and the Ottoman Empire was punctuated by conflict, with thirteen significant clashes between the two states over the course of just four hundred years, from the late seventeenth century to the early twentieth century (Kınıklığlu and Morkva 2007, 533); some of the bloodiest battles took place when the Ottoman and Russian Empires struggled for territory in eastern Anatolia leading up to and immediately following the First World War (Reynolds 2011). Prior to this period of emerging nationalism, however, distinctions between Muslims and Christians were not so clearly defined and people moved relatively freely between the empires. There were also various cross-border alliances and connections. For instance, from the midfifteenth to the mid-eighteenth century, Crimean Tatars, an offshoot of the Golden Horde, lived in the region of present-day Crimea (annexed/occupied by Russia in the spring of 2014) and pillaged surrounding regions to pay tribute to the Ottoman Empire. ${ }^{21}$ This included provisioning the Ottoman Court with slaves, as the Crimean Tatars had done in bringing Alexandra Lisowska, Hürrem, to Süleyman's Court around 1520 (Peirce 1993, 58). For hundreds of years Russia also sought to maintain equilibrium with the Ottoman Empire so it could maintain strategic access to the Black Sea Straits, a trade route which one-quarter of Russia's total exports passed through by the early twentieth century (Reynolds 2011, 32-33).

\section{Intimate Encounters and the End of Empires}

Istanbul is a city steeped in histories of encounter, where trade, diplomacy, and empires have intersected, forging a cosmopolitan milieu. This was especially the case 
in the second half of the nineteenth century following the Crimean (1853-1856) and the Russo-Ottoman (1877-1878) Wars, when people came to the city in ever greater numbers; between 1829 and 1884 the population of the city more than doubled in size, from about 359,000 to 895,000 people (Woodall 2015, 20). Even as the Ottoman Empire began to lose power, in 1885 the city was seen as a destination where, irrespective of religious background, young men could seek their fortune; nearly 60 percent of the population was born elsewhere and included sizable numbers of Greeks and Armenians (Karpat 1985, 104). ${ }^{22}$ However, by 1900 , with increasing strife in the region as European powers competed over Ottoman territory and opportunities shrank within Ottoman structures, the city became less diverse and the majority of the city's inhabitants were Muslim, a striking change from just fifteen years earlier (Karpat 1985, 86). ${ }^{23}$ The trend continued in the years leading up to and immediately following the First World War when an increasingly nationalist sentiment came to hinge on being Muslim. With atrocities against millions of Armenians and Greeks, as well as millions of Turks dying in the Allied onslaught on the Ottoman Empire, there was a subsequent massive population "exchange"; it is estimated that 1.2 million Christians departed Turkey for Greece and 400,000 Muslims left Greece for Turkey (Mansel 1985, 397; Reynolds 2011, 258). ${ }^{24}$

By 1918, when former Russian subjects first arrived in large numbers on the shores of Istanbul as refugees fleeing war and revolution, the population of the city had plummeted from nearly one million people prior to the First World War to about seven hundred thousand (King 2014, 113). The tens of thousands of Russian speakers who transited through and sometimes settled in the city were joined by the thousands of Allied troops overseeing the interwar period in Istanbul, as well as by refugees from Ottoman territories in the Balkans. This milieu was reminiscent of the second half of the nineteenth century, when waves of mobile populations brought diverse languages and a multitude of religious practices to punctuate public space. However, this time Russian speakers in particular shaped public space. In 1920, when Crimea was evacuated by the commanding general of the anti-Bolshevik White Army, General Wrangel, nearly 150,000 Russian speakers, many of them soldiers, arrived overnight on the shores of the Bosphorus. ${ }^{25}$ One author describes how "the streets of Constantinople were crowded with Russian officers, with the hungry, drawn look of refugees driving cabs, or selling newspapers, shoe-laces or wooden dolls" and they were concentrated in the area of Beyoğlu, a region historically associated with foreigners and encompassing present-day Taksim square (Mansel 1995, 398). ${ }^{26}$ In Galata, one of the long-standing enclaves of foreigners at one end of present-day Beyoğlu, a collection of small hotels became home to "Russian" prostitutes, and Russians dominated the entertainment of the city in a time that 
some have called the "Islamic jazz age" (King 2014, 7). Today Russian-speaking women entertainers like Irina are again visible in this part of the city in the side streets off present-day Istaklal Caddesi, the popular walking zone extending from Taksim Square to the Galata neighborhood featured in accounts of the 1920s.

In Pera, another Beyoğlu neighborhood along Istaklal Caddesi, which in the Ottoman era was host to foreign embassies and appealed to foreigners with its stylish establishments, Russian restaurants and clubs became synonymous with renegade nightlife. One entrepreneur, Frederick Bruce Thomas, an African American who had owned a series of jazz clubs in Petrograd, Russia, before the revolution, introduced the Charleston and the fox trot in his Istanbul club Maxim (Alexandrov 2013; King 2014, 138-42). In addition to the explosion of artistic productions and new forms of entertainment brought by those who arrived from Russia, there was the novelty of having wait staff who were women. According to one source, some Turkish men were reportedly "besotted" with Russian waitresses, who wore "high black boots, thin scarves . . . and heavy make-up," and others were appalled at what they saw as a bacchanalia (Mansel 1995, 339).

After the First World War Beyoğlu was widely associated with "decadent cosmopolitanism" in the form of social dancing, immoderate women's attire, and alcohol and drug use (Woodall 2015, 18). There were also a large number of

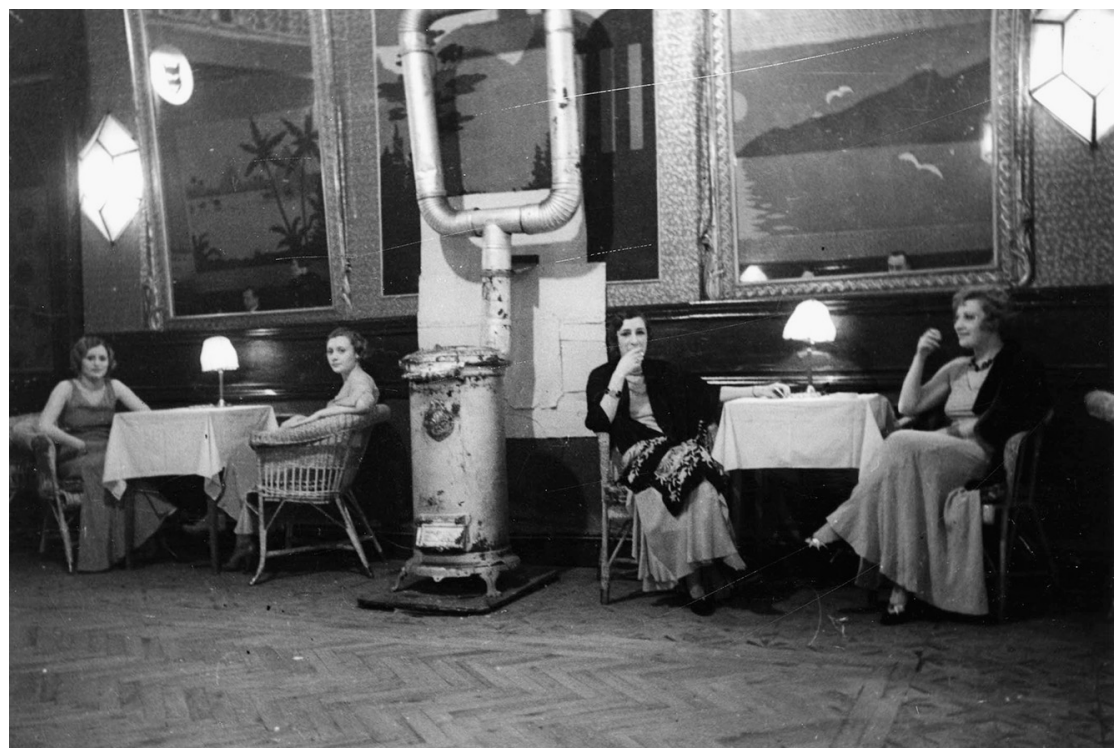

FIGURE 8. Four women at the Turan Bar in Beyoğlu (Pera), 1930s. Courtesy of Yapi Kredi Selahattin Giz Collection. 
Russian-speaking women, along with Greek and Armenian women, working as exotic dancers and in other forms of sex work (King 2014, 149). ${ }^{27}$ Public outrage targeted Russian women in particular and wives and widows of prominent men were the most vociferous. In 1923, a group of these incensed women sent a petition to the governor of Constantinople demanding the "expulsion of these agents of 'vice and debauchery who are more dangerous and destructive than syphilis and alcohol"' (Mansel 1995, 400). ${ }^{28}$ As Pelin Başc1 writes, for Turkish readers of fiction in the 1920s, even invoking the name of the neighborhood "Beyoğlu" was sufficient to summon up images of immoral behavior on the part of the largely non-Muslim population that lived there $(2003,160){ }^{29}$

Public pressure let up as most Russians gradually emigrated abroad, and Russian women were no longer visible figures in leisure spaces of Istanbul. By 1934 the Turkish state had granted citizenship to just 986 remaining "White Russian" families. ${ }^{30}$ While in this period the Turkish state especially favored the highly educated, aristocratic, so-called "White Russians" who were fleeing the Soviet Union, just a few years later anxiety over communism and suspected espionage led to a 1937 Turkish government order to refuse admission to nearly all refugees from the Soviet Union, and border crossing in the region was virtually curtailed, even for those with relatives just across the border in present-day Georgia (Pelkmans 2006). ${ }^{31}$

\section{After the Cold War and the "Soft Power" of Turkey}

For over fifty years there was minimal interaction between Turks and the former Soviet Union. Turkey was effectively on the front lines of the Cold War, with more than half of its national budget in the late 1940s and early 1950s spent on defense (Machado 2007, 94). ${ }^{32}$ The Marshall Plan in Turkey brought about new agricultural technologies and road-building expertise, as well as educational training, all key in Cold War mandates to transform countries like Turkey that were thought to be vulnerable to the spread of communism. As then US Secretary of Commerce Averill Harriman emphasized, creating an economically prosperous Turkey was meant to be an "effective deterrent to Soviet aggression" (Machado 2007, 94). In fact, whether or not directly the result of the Marshall Plan, in the years following its implementation, the Turkish gross national product (GNP) surged, with a 40 percent increase from 1950 to 1952 alone, and the primary export shifted from tobacco to cotton, a product for which there was an enormous global demand (Machado 2007, 95). Unlike in some countries where the Marshall Plan was carried out, in Turkey the phenomenal economic transformation did not automatically predispose the country to embrace US policy initiatives or bring about a sense of economic and ideological direction in common with the United States. 
Despite the Marshall Plan, for decades after the Second World War Turkey struggled economically and its growing population was underemployed, something that turned out to be a boon to postwar Germany.

In the aftermath of the sudden erection of the Berlin Wall in 1961, West Germany lost a key source of low-wage labor for its expanding economy, and Turkey became the new source. In the decade following the appearance of the wall, more than a million Turks traveled to Germany as "guestworkers," and fifty years later more than three million immigrants of Turkish heritage lived in Germany (Mandel 2008, 6). For decades Turkey was wary of becoming the source country for Europe's demands for human labor and raw materials. However, there was even more widespread wariness about Soviet power, on the one hand, and, on the other, about US desires for access to land for establishing military bases.

All this began to shift by the late 1980s for a number of reasons. First, as the Cold War let up and the Soviet Union's staunch political and economic positions began to waver, Turkey increasingly turned to Russia as a source of gas and oil. Nearly simultaneously, Turkey's domestic political and economic balances of power shifted, and like some other expanding economies of the 1980s (Bishop and Robinson 1998), Turkey fostered the service sector, and especially the tourism, hospitality, and entertainment industry while opening up its manufacturing to world markets (Tosun 2001). ${ }^{33}$ These expanding sectors brought about an increased demand for low-wage labor, which drew rural Turks, predominantly men, into new economic spheres in urban locations but also made it profitable to hire undocumented foreign workers. By the early 1990s, for the second time in the course of a century, Russian speakers traversed borders into Turkey in large numbers, this time not as refugees, but in search of work. By the early 2000s not only labor migrants from across the former Soviet Union but also Russia's growing middle class was visible on the Turkish landscape as people flocked to Turkey as vacationers and basked in the flourishing tourism economy; in 2011 alone 3.5 million Russians entered Turkey on tourist visas (UNWTO 2012, 6-7). ${ }^{34}$

The arrival of such a large volume of relatively affluent Russian-speaking tourists created a whole new sphere of trade and cultural exchange, as well as exchange of services and goods. ${ }^{35}$ In appealing to these tourists, the Turkish tourism industry created niches for low-wage post-Soviet migrants as well. It was not uncommon for migrants to combine selling luxury goods near the seaside with their own budget vacation with friends or family arriving from Belarus or Ukraine or Moldova. Antalya, a resort city on the Mediterranean Sea, became particularly popular with Russian speakers in the 1990s. As one woman, a shop assistant and sometime trader from Moldova, explained, each year she spent her vacation time in Antalya selling furs to Russian tourists; in 2011 she made $\$ 4,000$ in two months, more than double what she calculated she could have made over 
the same period working as a shop assistant in Istanbul. For Turks as well, the expansion of the tourism economy shaped their professional lives, and during my research I frequently met Turkish men working as staff in hotels or as taxi drivers who told me in fully functional Russian that they chose to learn Russian as a way to improve their employment options in the tourism sector.

In addition to tourism, pilgrimage is a related area of increased interaction between Turks and Russian speakers. Pilgrimage from the former Soviet Union grew extensively in the early 2000s as Turkey sought to foster "faith tourism" by investing in restoring early Christian sites and enabling archaeological study of some of the oldest churches in the world (Güsten 2011). ${ }^{36}$ Long-term labor migrants I came to know in Istanbul also sought out Eastern Orthodox ritual sites as part of their daily lives in the city. In particular, each April 23 several of my interviewees made a point of visiting Aya Yorgi Garibi (the Monastery of St. George) a popular pilgrimage site located high on the peak of Yücetepe on Büyükada, an island near Istanbul. ${ }^{37}$ They joined tens of thousands of people traveling from a great number of places-including Turkey, Russia, Greece, and the Balkans-to take part in what is known as an ancient fertility ritual, but they also took part in rituals like unwinding a string along the steep path leading up to the monastery, just in case this might bring about better fortunes overall (Couroucli 2010; Schillinger 2011, TR1). ${ }^{38}$ Even when migrants did not take part in this annual pilgrimage, many attended church at least on major holidays. Many middle-aged Moldovan Gagauz women I met made a point of going to church for Easter (Paskha) and Pentecost (Troitsa), usually at St. Pantaleimon, a small Russian Orthodox church that holds Sunday services on the sixth floor of a building in the harborside Istanbul neighborhood of Karaköy. ${ }^{39}$

Cultural and religious tourism have certainly forged renewed connections between Turkey and Russia. Nevertheless, perhaps the single largest link between the countries since the 1990s has been Turkey's reliance on Russia as a source of energy. By 2008 Turkey came to rely on Russia for nearly two-thirds of its gas supply and one-third of its oil needs (Ediger and Bağdadi 2010, 233). ${ }^{40}$ Turkey continues to seek ways to attract Russian capital and create a more equal balance of trade ${ }^{41}$ As part of this effort, since the early 1990s Turkey has maintained a relatively open border with Russia and with other former Soviet states, making it fairly easy for temporary workers like Irina, the entertainer who first told me about Hürrem, and Zhenia, the shuttle trader traveling from central Siberia, to enter Turkey as tourists. For over twenty years Turkey granted mostly one-month tourist visas on entry to citizens of former Soviet countries, and as of 2013 state-tostate agreements extended visa-free entry into Turkey for two or three months for many citizens of countries of the former Soviet Union. ${ }^{42}$ In turn, Russia also relaxed visa requirements for Turks, thus facilitating the growth of Turkish companies that 
have increasingly won tenders for major construction projects in Russia, as well as the mobility of the more than seventy-five thousand Turks who were employed as of 2012 in countries of the former Soviet Union (İçduygu and Biriz Karaçay 2012; İçduygu 2009, 282). With some variation from year to year, Russia has also tacitly agreed to overlook import duties on the "suitcase" or informal trade of apparel from Turkey into Russia, a topic to which I return in chapter 2. This particular configuration of a flexible border regime into Turkey is a critical aspect of the multibillion dollar bilateral investment of Turkey and Russia (Kınıklığlu and Morkva 2007), something that helps explain the existence of thousands of undocumented migrants from the former Soviet Union working long-term in Turkey.

\section{Soft Power and the "Turkic Sphere"}

The demise of socialist state infrastructures and the reworking of regional alliances created a fertile ground for Turkish influence in Eurasia. In the case of the Turkic-speaking Gagauz, for instance, as their status within Moldova became tenuous in the early 1990s, the then Turkish president, Süleyman Demirel, played an important role in positioning Turkey as a mediator in the arrangement that unfolded, and the Gagauz were ultimately granted significant administrative autonomy (Demirdirek 2008; Şenyuva 2012). In addition to such mediator roles in the 2000s, Turkish government aid packages and NGO and benevolentassociation ventures continued to widely promote historical links with Turkey as part of Turkish "soft power" or indirect influence over states in Eurasia (AngeySentuc and Molho 2015; Kaya 2013, 68; Ghodsee 2009, 134, 140). Turkey has been careful to avoid creating tensions with neighboring governments, even as it has positioned itself as a political force. Established in 1992 to provide aid within the "Turkic sphere," encompassing southern Bulgaria and Central Asian states as well as southern Moldova, the Turkish Agency for International Development and Cooperation (TIKA) is one of the key actors overseeing the distribution of Turkish aid (Şenyuva 2012). In its work in southern Moldova the agency has sponsored a number of initiatives, including the training of Gagauz teachers in Turkey, the construction of sewage and water projects, and the reorganization and funding of a new health infrastructure. ${ }^{43}$ Furthermore, as in Central Asia, Turkish government aid has also supported several schools in southern Moldova with an emphasis on Turkish language and culture. Alongside Turkish government aid efforts, the Fethullah Gulen movement has also had substantial influence in the region, namely through an extensive network of its own schools (Hudson 2008; Putz 2016). ${ }^{44}$

Turkey's effort to deploy soft power in the region could be seen as a form of exchange for the wide-ranging care work Moldovan women provide in Turkey, 
a situation many in Moldova consider to be to the detriment of women's own households (Keough 2015). Several people in southern Moldova told me they were cynical about Turkey's motivations, but they willingly accepted the assistance that arrived in the form of a newly constructed hospital, improved road system, and an expansion of educational opportunities; especially for Gagauz, as I discuss in chapter 3 , the presence of the Turkish state provides them with forms of power vis-à-vis the Moldovan state. However, a critical assessment of Turkey's humanitarian projects suggests that they are integrally linked to Turkey's desire to showcase its ability to "help" Turkic brethren even as Turkey does little to create social protections for the thousands of migrant women laboring in Turkey without benefits and in fear of deportation, a dynamic described as "neohumanitarian" in other locations (Ticktin 2011). In this way, the poorly paid, largely female post-Soviet labor force in Turkey is a key part of the story of Turkey becoming a global force, capable of flexing its "soft" power, but also relying on newly mobile, flexible labor.

\section{Politics of Gender and Intimacy in Turkey}

In many ways, Turkey is a country of extreme dichotomies. It boasts an infrastructure on a par with that of many wealthy, industrialized countries in terms of financial institutions, road systems, and health care. Moreover, with 70 percent of the population urban-based, a growing middle class contributes to a cosmopolitan Turkey where men and women have access to higher education, urban fertility is considerably lower than the countrywide average, feminist organizations play an important role in public discourse, and women form a significant portion (34 percent) of all professionals in recent years (Sirman 1989; Countries 2002; Coşar and Gençoğlu Onbaşı 2008; Turkstat 2012) ${ }^{45}$ However, in 2014 Turkey also had the highest level of gender inequality of all Organization for Economic Cooperation and Development (OECD) countries (UNDP 2016). ${ }^{46}$ According to some metrics, in 2015 Turkey was poised to make significant improvements to gender inequality, but in the areas of women's economic and political participation this was not the case (World Economic Forum 2015). ${ }^{47}$ In general, there is a dual reality in Turkey, where the politics of gender for an elite and growing urban middle class have been very different than for the rural, working-class, and poor populations.

Transformations in household forms of power in Turkey have occurred in diverse ways across the country over the twentieth century. However, these changes became most evident from the early 1970s as Turks became increasingly part of transnational circuits of migration into Germany (Mandel 2008), and then by the late 1970s as Turkey's government took on IMF loans and initiated neoliberal reforms, including curtailing public-sector spending, moving away 
from agricultural production, and putting resources into the export sector (Keyder 1999; Naylor 2004, 93-94). ${ }^{48}$ By the 1980s Istanbul became the center for Turkey's intensive engagement with world markets (Öncü 1999, 104). Along with the rapid increase in foreign investment and sharp rise in exports from Turkey, the service sector suddenly grew. As in many other locations of rapid integration into world markets, by the early 1990s Turkey had opened its borders to new migrants who conveniently contributed to the supply of low-wage labor while also becoming a visible reminder of radical shifts in the Turkish economy and urban cultural landscape. Along with millions of households becoming transnational, millions of Turks have also moved into Turkey's urban centers, creating enclaves of rural migrants that have rapidly increased the populations of large cities such as Istanbul, Ankara, and Izmir (İçduygu et al. 2013, 16-17; Karpat 2004). ${ }^{49}$ In sites like these Turkish women have widely become integral to home-based production, and especially piecework, where they produce textiles and engage in knitting or sewing (White 2004; Dedeoğlu 2008), and some women have also been employed as live-out domestic workers (Akalin 2007). ${ }^{50}$ In 2012 the vast majority of women (more than 75 percent) were not employed outside their homes, and many scholars point to this to explain the unequal access to economic opportunities that remains a key issue for women in Turkey (Müftüler-Baç 2012; Hausmann et al. 2012, 15). ${ }^{51}$

Although profound transformations in legal provisions for gender equality accompanied the creation of the Turkish Republic in 1923, as Deniz Kandiyoti (1987) has written, women were "emancipated but unliberated." A wide range of legislation introduced in the early Republican era, as well as in more recent decades, brought about reforms, including expanding the right to education for girls and women and regulating when and where the veil could be worn. Nevertheless, family and household domains in Turkey have remained largely defined by patriarchal structures, with men's prerogatives governing decisions around fertility, education, and mobility; challenges to men's power may be one of the factors contributing to pervasive domestic abuse and disturbing levels of violence against women that appear to have escalated in the early 2000s (Koğacioğlu 2004; Jones 2011).52

Ayşe Parla argues that the foundations for contemporary politics defining gender inequalities can be found in the 1920s, when "notions of being modern became articulated" in Turkey $(2001,70)$. As Parla notes, with the newly minted Constitution, the state was able to proclaim women to be equal citizens and thereby dispel concerns about the role gender and male privilege might play in perpetuating inequality $(2001,70-73) \cdot{ }^{53}$ For instance, in 1930 Turkish women gained the right to vote in municipal elections, and by 1934 in national elections, placing Turkey solidly within the trend for European countries of the time. However, in crafting women as new Turkish citizens, and creating the means for 
women to pursue careers in the realms of education, medicine, and beyond, the state simultaneously proclaimed it women's duty to be good wives and mothers; women were incorporated into the nation, but with the primary task of reproducing the family for the benefit of the state (Arat 1994; Koğacioğlu 2004, 127-28). Thus, in Turkey today, in many ways men and women are fundamentally framed as having very different rights and being subject to different forms of social control, inequities that Turkish feminists have consistently challenged since the 1980s, and more recently sought to address as Turkey has aspired to EU accession. $^{54}$

In addition to gender inequities written into the actual legal code, the way women's sexuality was framed by the 1923 Constitution also continues to have ramifications for women. With the establishment of the Turkish Republic, any idea of sexuality was purged from the way the new nation of Turkey positioned women. Women were to be "modern," both in appearance and in having access to formal education, but to be shielded from any associations with sexuality, a sign of a different, unwelcome version of modernity. Women were to be modern but modest, ideal citizen-mothers, a situation not unlike what Daphne Berdahl (1999) describes for late state socialism and "worker-mothers" in East Germany. As Berdahl notes, "the rights and privileges accorded to women under state socialism as well as its ideology of worker-mothers also served to reinforce as 'natural' women's traditional role in the home, thereby underscoring as well women's roles as biological regenerators of the socialist nation and as socializers of its citizens" $(1999,190)$. Likewise, as Kandiyoti writes about Turkey, "the national ideal was of a self-sacrificing comrade-woman [who was] also an asexual sister-in-arms" (1988a, 46).

Decades after the establishment of the Turkish Republic, women's modesty continues to be widely valued and signified in the form of virginity, something that resonates well beyond simply a sign. Until the early 2000s the Turkish state brandished the stick of "virginity" tests to discipline women and girls into conducting themselves "modestly" (Parla 2001; Frank et al. 1999). ${ }^{55}$ While the 2004 Penal Code made virginity exams illegal, in the 2010s the state still reserved the right to require these in cases where moral questions were considered pertinent to legal proceedings. Related to this policing of women's sexuality, periodic exams intended to regulate moral conduct continued to be a part of the mandated monthly medical checkups for dancers I came to know in Istanbul in $2001-2011.56$

Even if virginity exams are no longer legal, state regulation of women's sexuality remains firmly in place and is bluntly invoked as an issue of national debate. In comments made in May 2012 at the third annual congress of the women's branch of his party, Prime Minister Recep Tayyip Erdoğan declared that he would 
seek to outlaw abortions, except in the case of extreme medical conditions, and significantly curtail access to cesarean procedures. ${ }^{57}$ Turkish feminists responded vehemently, opposing these attacks on women's control of their own bodies. One then MP of the main opposition party, the Republican People's Party (CHP), Aylin Nazliaka, boldly stated, "The Prime Minister should stop standing guard over women's vaginas." Nazlıaka was in turn castigated by a number of politicians for using "vulgar" language and for daring to refer to women's sexuality (Sehlikoğlu 2013).

Turkish feminists argue that the struggle for gender equality in Turkey is a key part of the larger struggle for a more pluralist and inclusive democracy (llkkaracan 2012). Some argue that, like Kurds who have demanded the use of their native Kurdish for the purposes of education, women should also be more extensively incorporated into the body politic as equals. Feminist scholars point to a range of ways in which male privilege defines public culture, including by making women feel like "interlopers in public spaces" (Kandiyoti 2011) but also by making it socially acceptable for men, but not women, to have lovers, as I discuss in chapters 4 and 5 .

As I show in the following chapters, the politics of gender in Turkey, whether at the household level, enshrined in law, or embodied in telenovelas such as The Magnificent Century, are integrally tied to post-Soviet migrant women's longterm transnational circuits linking post-Soviet space to Istanbul. 
